\title{
A Heterotrophic Synchronous Culture of Chlorella
}

\author{
Takao Nishimura, Raghunath Ramu Pachpande* and Tatsuichi \\ Iwamura**
}

Research Institute for Biochemical Regulation, Faculty of Agriculture, Nagoya University, Nagoya 464, Japan

\begin{abstract}
Based on the observation that photoautotrophically grown Chlorella cells fail to complete cell division under anaerobic condition in the dark, we devised a heterotrophic synchronous culture (HSC) system for this green alga. The system consists, at a temperature of $21^{\circ} \mathrm{C}$, of a $32 \pm 1 \mathrm{~h}$ period under $3 \% \mathrm{CO}_{2}$ in air and the successive $12 \pm 1 \mathrm{~h}$ period under $0.5 \% \mathrm{O}_{2} \pm 99.5 \%$ $\mathrm{N}_{2}$ (the sum of the two periods is equal to $44 \pm 1 \mathrm{~h}$ ), using a semi-balanced medium containing glucose in an inorganic salt solution. This procedure could be successively repeated several times and the division index was practically $100 \%$, as it is for Chlorella in the photoautotrophic synchronous culture (PSC). We believe this is the first successful HSC achieved by the method of alternating atmospheric oxygen tension.

Synthetic patterns for DNA, RNA and protein as well as chlorophyll during the cell cycle of Chlorella in HSC were similar to those observed in PSC, and the respiratory activity of actively growing cells in HSC was twice that of those in PSC. It is hoped that this system, under the regimen of high and low oxygen tension, can be utilized for other eukaryotic cells.
\end{abstract}

The unicellular green alga, Chlorella (15) and a budding yeast (12) are the organisms for which a useful technique in cell biology, the synchronous culture, was first developed. An excellent system under a light-dark regimen, established later, has long been utilized in our laboratory for studies of the cell cycle from physiological, biochemical and molecular biological viewpoints $(1,4,6,7,8,13)$. In the system, the major energy metabolism is due to a single large chloroplast and the role of a single mitochondrion is obscure. Yet it was observed (15) that the large algal cells, grown photoautotrophically, carried out cell division and "cellular" division (liberation of daughter cells from a mother cell; $\mathrm{Cf}$. (14)) aerobically in the dark, but could not fulfil the cellular division at least under anaerobic conditions $\left(\mathrm{N}_{2}\right.$ atmosphere) in the dark. Thus, the mitochondrion is certainly indispensable for algal cell proliferation. This prompted us to examine the possibility of establishing HSC for the alga in order to help clarify the role of the mitochondrion in the alga as well as in other green cells.

We report here the establishment of a heterotrophic synchronous culture system

\footnotetext{
* Present Address: Dept. of Botany, Poona Univ., Pune 7, India.

** To whom correspondence should be addressed.

Abbreviations used: PSC, photoautotrophic synchronous culture; HSC, heterotrophic synchronous culture; HOP, high oxygen tension period; LOP, low oxygen tension period; PCV, packed cell volume.
} 
for Chlorella and some of its characteristics in terms of respiratory activity and biomolecular syntheses.

\section{MATERIALS AND METHODS}

Materials. All the reagents used were of reagent grade. All water used was deionized with ion exchangers and filtered through a Millipore filter.

Algal Culture. The algal strain was Chlorella ellipsoidea (Tamiya's strain), which has long been used in our laboratory for cell-cycle studies in $\operatorname{PSC}(1,8,13)$. Based on previous data $(3,10)$, a mean elementary composition of the algal cells in the cell cycle can be formulated as

$$
\mathrm{C}_{9.863} \mathrm{H}_{18.50} \mathrm{O}_{5.625} \mathrm{~N}_{1.583} \mathrm{P}_{0.1613} \mathrm{Mg}_{0.05141} \mathrm{Fe}_{.0002586}
$$

Based on this formula, we devised a semi-balanced medium containing: glucose, 22; $\mathrm{KNO}_{3}$, 6.2; $\mathrm{KH}_{2} \mathrm{PO}_{4}, 5.1 ; \mathrm{K}_{2} \mathrm{HPO}_{4}, 2.2$ (50 mM phosphate buffer); $\mathrm{MgSO}_{4}, 0.51 ; \mathrm{FeSO}_{4}, 0.030$; EDTA, 0.080 , in grams per liter at $\mathrm{pH} 7.0$. The medium was semi-balanced in the sense that the major constituents would be consumed simultaneously. In addition, the medium contained a mixture of microelements as was in the photoautotrophic culture (15).

The algal heterotrophic growth in this medium was carried out at $21^{\circ} \mathrm{C}$ in the dark by bubbling $3 \% \mathrm{CO}_{2}$ in air through the culture, as in the photoautotrophic growth studies. The inoculum for the synchronous culture was obtained from the heterotrophic asynchronous culture, where the algal cells were in the exponential growth phase at the cell population density below $4 \mathrm{ml}$ packed cell volume $(\mathrm{PCV}) / 1$ culture (in the following this value will be abbreviated as $4 \mathrm{ml} / \mathrm{l}$ ); the culture was diluted ten-fold and subjected to differential centrifugation in a large centrifuge using vessels of $20 \mathrm{~cm}$ in length. The small cells obtained, which corresponded to " $D_{a}$ " cells (the small, dark green, photosynthetically active cells at the start of the cell cycle in PSC $(13,14))$, were used as the starting cell material. The efficiency of cell fractionation was usually below $10 \%$. The smaller cells collected were inoculated into a fresh culture medium in a $500 \mathrm{ml}$ glass culture vessel (15).

Respiratory activity. Algal respiration was assayed polarographically using a YSI 4004 Clark Oxygen Probe (Yellow Spring, Ohio, U.S.A.) (2). The cell density was adjusted to $10-20 \mathrm{ml} / 1$ with fresh culture medium, and the $\mathrm{O}_{2}$ consumption was measured at $21^{\circ} \mathrm{C}$ in the dark.

Assay of cell constituents. Chlorophyll, protein, RNA and DNA were assayed by the method of Iwamura et al. (9).

\section{RESULTS}

Algal heterotrophic growth in batch culture. A batch culture of the algal nonsynchronous, heterotrophic growth is shown in Fig. 1. The semi-balanced culture medium could support the algal growth starting from a small population density up to about $40 \mathrm{ml} / 1$ (e.g., from 0.34 to $42 \mathrm{ml} / \mathrm{l}$ ). The algal cells grew exponentially up to $15 \mathrm{ml} / \mathrm{l}$; the relative growth rate per day, being defined as $\left[24 /\left(t_{2}-t_{1}\right)\right] \times \log _{10}$ (V2/V1) (V2, V1: PCVs at the $t_{2}$ th, $t_{1}$ th $h$, respectively), was 0.44 , which was equal to one half of that under the photoautotrophic conditions (15). When the phosphate buffer concentration was $10 \mathrm{mM}$ (the same as that in the photoautotrophic culture), the $\mathrm{pH}$ of the culture changed continuously to about 8 . However, when the concentration was $50 \mathrm{mM}$ (used throughout this work), the $\mathrm{pH}$ remained at 7.0 until the population density was a little over $4 \mathrm{ml} / 1$. This led us to consider the operational 


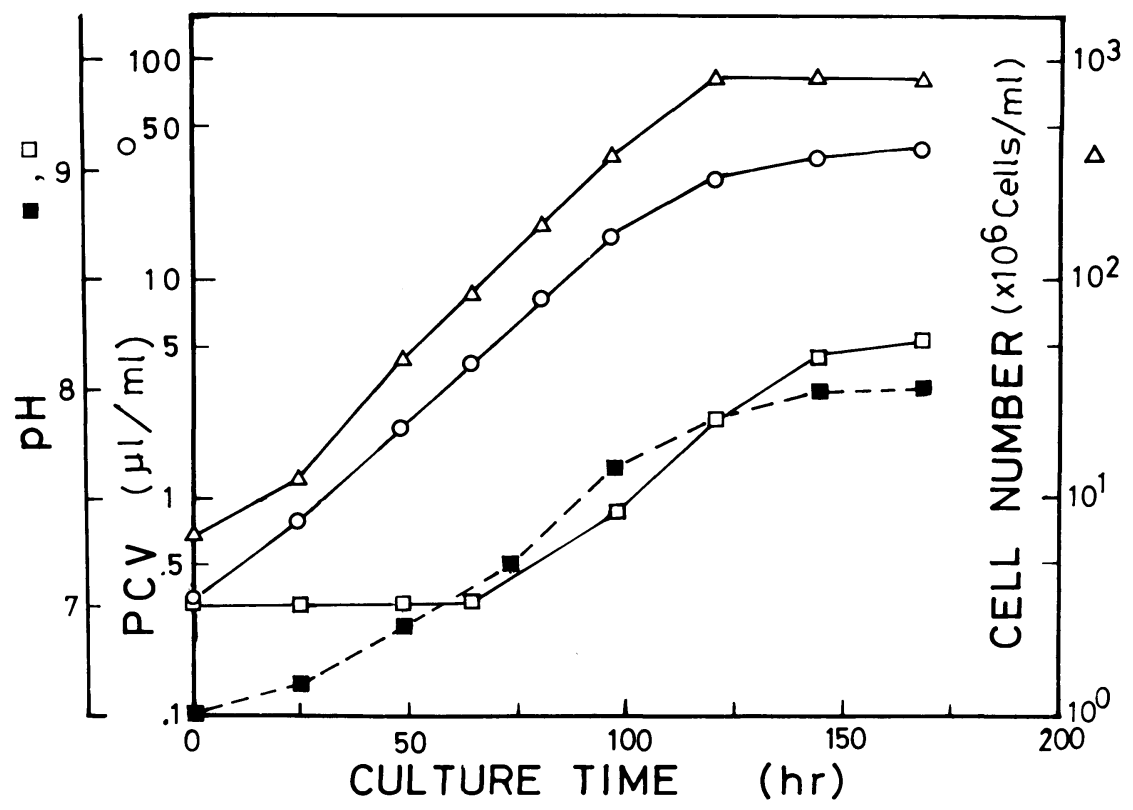

Fig. 1. Heterotrophic growth in a batch culture. The algal cells were inoculated at $0.34 \mathrm{ml} / 1$ into $500 \mathrm{ml}$ of the semi-balanced medium at $21^{\circ} \mathrm{C}$. Three percent $\mathrm{CO}_{2}$ in air was bubbled through the culture . Circles: PCV; triangles, cell number; open squares, $\mathrm{pH}$ at $50 \mathrm{mM}$ phosphpate-buffer; solid'squares, $\mathrm{pH}$ at $10 \mathrm{mM}$ phosphate buffer.

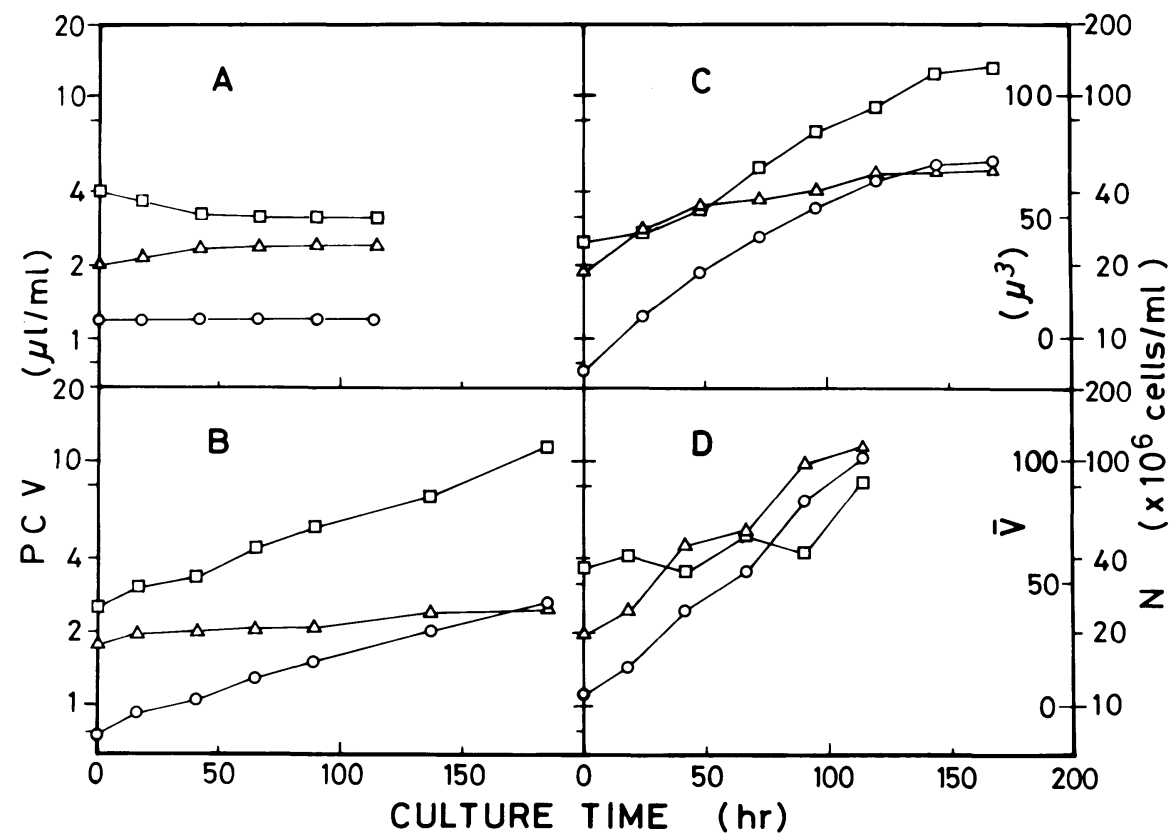

Fig. 2. Effect of oxygen tension on algal growth. The percentage of atmospheric oxygen in $\mathrm{N}_{2}$ gas were: $\mathrm{A}, 0 \% ; \mathrm{B}, 0.5 \% ; \mathrm{C}, 1.0 \% ; \mathrm{D}, 2.5 \%$. Circles, PCV; triangles, cell number $(\mathrm{N})$; squares, mean cell volume $(\overline{\mathrm{V}}=\mathrm{PCV} /$ cell number $)$. 
population density for the synchronous growth to be ideally in the range of $0.5-$ $4.0 \mathrm{ml} / \mathrm{l}$ and permissibly up to $10 \mathrm{ml} / \mathrm{l}$ (the higher the density, the easier the handling of the culture for various analyses).

Effect of oxygen tension. We then examined the effect of oxygen tension in the bubbling gas (bubbling prevented sedimentation of the cells) on the algal cells that had been actively grown in $3 \% \mathrm{CO}_{2}$ in air and then transferred to another oxygen tension in $\mathrm{N}_{2}$ (Fig. 2). Upon the transfer to $0 \% \mathrm{O}_{2}$, the increase in cell mass of the algal cells stopped completely, while the cell number increased slightly, but only during the early period. In the later period, the cell number remained unchanged. However, upon transfer to $0.5 \% \mathrm{O}_{2}$, the algal cells continued to grow though at a low rate; the cell mass increased more quickly than the cell number. With increases in $\mathrm{O}_{2}$ tension, the algal cells grew at higher and higher rates, gradually reaching

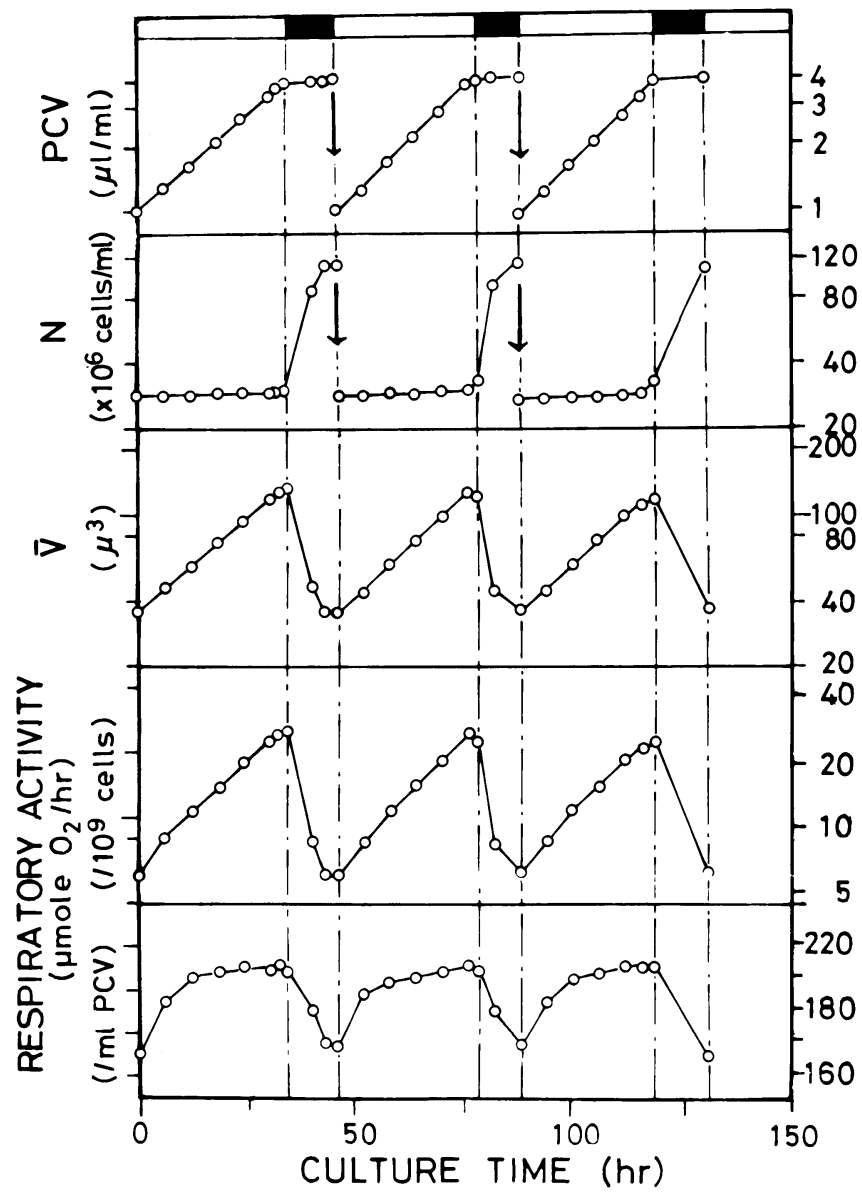

Fig. 3. Heterotrophic synchronous culture of Chlorella. Open and solid bars at the top of the figures denote HOP $\left(3 \% \mathrm{CO}_{2}\right.$ in air) and LOP $\left(0.5 \% \mathrm{O}_{2}+99.5 \% \mathrm{~N}_{2}\right)$, respectively. The cell cycles shown are the successive cycles from the first cycle, where the culture started from the small cells obtained from the asynchronous heterotrophic culture (corresponding to " $D_{a}$ " cells in PSC; see the text and also Fig. 4). The arrow indicates dilution ( 4 fold) of the culture with the fresh medium. See also the legend of Fig. 2. 
steady state growth, where the rate of increase in cell mass was same as that in cell number. Thus, we could expect that, at the lowest oxygen tension tested $\left(0.5 \% \mathrm{O}_{2}\right.$ $+99.5 \% \mathrm{~N}_{2}$ ), the mature algal cells that had attained nearly full cell size under $3 \%$ $\mathrm{CO}_{2}$ in air might carry out the whole process of cell division.

We then searched for an appropriate duration of growth under the high $\mathrm{O}_{2}$ tension $\left(3 \% \mathrm{CO}_{2}\right.$ in air) and the minimum duration necessary under the low $\mathrm{O}_{2}$ tension $\left(0.5 \% \mathrm{O}_{2}+99.5 \% \mathrm{~N}_{2}\right)$ to establish the heterotrophic synchronous culture system under "high and low oxygen tension regimen".

Heterotrophic synchronous culture system. The characteristics of the heterotrophic synchronous culture system thus established are shown in Fig. 3. Periods for the high $\mathrm{O}_{2}$ tension (HOP) and the low $\mathrm{O}_{2}$ tension (LOP) were determined to be $32 \pm 1$ and $12 \pm 1 \mathrm{~h}$, respectively (the sum of the two periods was $44 \pm 1 \mathrm{~h}$ ). The growth curves in terms of PCV and cell number per unit culture volume were very similar to those in the autotrophic synchronous culture $(8,13)$. The cell mass increased exponentially during HOP, reaching $3.93 \pm 0.03$ times that at the start of the cell cycle, the zero hour $\left(\mathrm{T}_{0}\right)$, while no increase in cell number occurred. During the successive LOP, both the cell and cellular division occurred, resulting in four daughter cells from one mother cell, as in PSC, while the cell mass increased slightly to reach $4.02 \pm 0.02$ times that at $T_{0}$. Changes in the cell size distribution during the time course (Fig. 4) guaranteed that the growth was due to a homogeneous cell population, which is an essential feature in synchronous culture. The system was repetitive so that we could repeat the whole cell cycle successively five or more times until the culture suffered from contamination by fungi or bacteria.

Respiratory activity. Energy metabolism in the heterotrophically grown algal

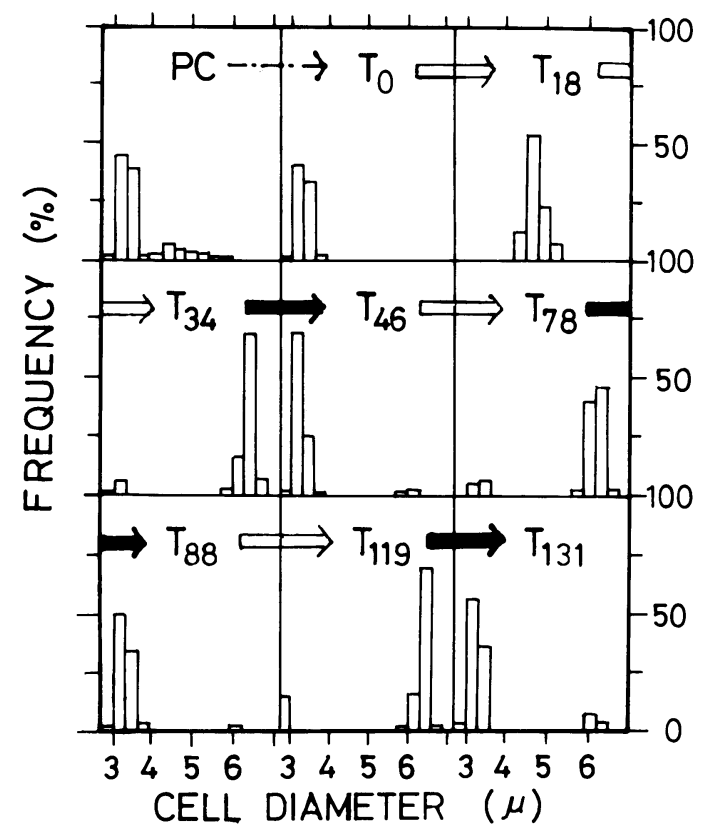

Fig. 4. Changes in cell size distribution of Chlorella during the heterotrophic cell cycle. PC: the preculture under heterotrophic asynchronous conditions (see the text and the legend for Fig. 3). 

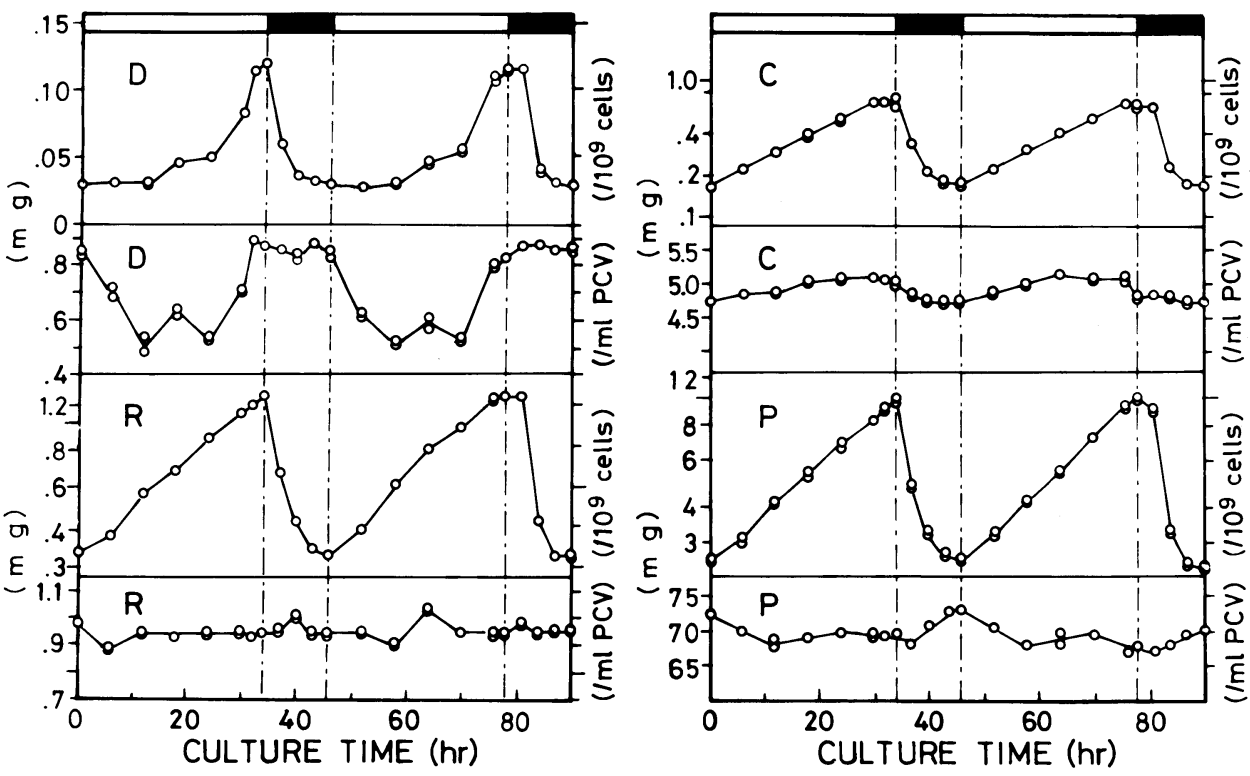

Fig. 5. Changes in the content of DNA, RNA, chlorophyll and protein during the heterotrophic cell cycle of Chlorella. For each of the cell constituents, the content was shown both per cell basis and per cell mass basis. D, DNA; R, RNA, C, chlorophyll; P, protein. See legend for Fig. 3.

cells is due solely to respiratory activity by the single mitochondrion and its change during the cell cycle is closely related to the mitochondrial division cycle, as has been noticed in PSC $(4,13)$. The characteristic changes in activity are shown in Fig. 3. We observed a lowering of the activity during LOP and a rapid activation during the early phase of HOP (the same trend was also observed in the dark and the early phase of the light period in PSC, respectively), and a high and fairly constant activity (per cell mass basis) between these two periods. Interestingly, the respiratory activity at the high and constant value was exactly twice that found in the autotrophically grown cells (14).

Synthetic patterns of biomolecules. A synchronous culture system can be characterized by the patterns of synthesis of various biomolecules together with changes in cellular activities during the cell cycle, among which the pattern of DNA synthesis is most important. The DNA, RNA, protein and chlorophyll contents (this algal strain synthesizes chlorophyll actively even under the heterotrophic condition) were assayed during the cell cycle, as shown in Fig. 5.

All these synthetic patterns resembled, as a whole, those found in $\operatorname{PSC}(5,7,8$, 13) (the rate of mass increase was lower in HSC than in PSC). This indicated the active mass increase was due to active syntheses of both RNA and protein during HOP, which consisted of G1-and S-phases (as during the light period in PSC), and the whole process of cell division during LOP (as during the dark period in PSC). Above all, it is remarkable that the two-step increase in the DNA content was exactly the same as that observed in $\operatorname{PSC}(5,8,13)$ with respect to the relative timing and the relative increase in quantity. 


\section{DISCUSSION}

The synchronous culture system described above is the first heterotrophic synchronous culture system for green cells, and also the first successful one performed by the gasometric method, the high- and low oxygen-tension regimen. (There was one report of an unsuccessful trial of an HSC on an amoeba by the gasometric method, the alternation of bubbling with $\mathrm{N}_{2}$ and air, with no result shown (11)). Our system produced repetitive results as well as a division index of almost $100 \%$. These findings were comparable to those in PSC. The stress imposed on the culture to obtain the excellent repetitiveness resulted in transitional phenomena represented by changes in respiratory activity that might be mainly due to cell adaptation to the changes in atmospheric $\mathrm{O}_{2}$ tension. This kind of transitional effect is rather inescapable in such a synchronized culture system. In PSC, where the culture is under the light-dark regimen, photosynthetic and respiratory activities decrease in the dark and recover rapidly upon illumination $(4,13)$. However, the system is considered to be useful for investigating the events and the regulatory features in a cell division cycle under heterotrophic conditions for green cells. The merit of the cell-synchronization appears to be that the stress is not as drastic or harmful for cell functions. Hence, the system may be applicable for other green cells and nongreen cells, including animal cells.

The increase in the DNA content in the middle of HOP appeares to arise from the replicative synthesis of the algal chloroplast DNA, followed by that of nuclear DNA, as was proved in PSC $(3,8)$. Correspondingly, the content of chlorophyll

Nucleus

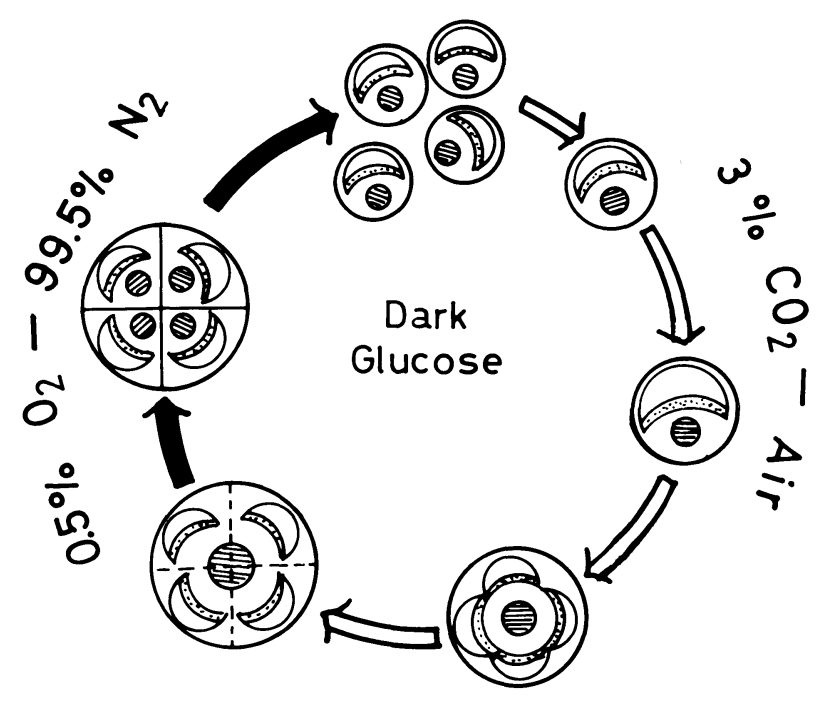

$\triangle$ Chloroplast Mitochondrion

Fig. 6. A schematic sketch for the heterotrophic cell cycle of Chlorella. For the single mitochondrion, the division cycle is assumed the same as in PSC. 
increased significantly after the middle of HOP, but was reduced during LOP to the level at the beginning of the cell cycle. Although nothing can be concluded about the replicative synthesis of the mitochondrial DNA at this moment, the events in HSC in the division cycle for the three DNA-containing organelles, nucleus, chlotoplast and mitochondrion, may be almost the same as those in PSC, as illustrated in Fig. 6.

As stated, the higher and constant respiratory activity of the heterotrophically grown cells (the growth rate being maximal) was exactly twice that in the algal cells growing at the maximum rate under photoautotrophic conditions (using nitrate as the nitrogen source) (4). Thus, it is interesting to examine whether or not the mitochondrial DNA content in HSC is twice that in PSC in order to cope with the demand for biosynthetic energy under the nutritional conditions.

The final yield of the algal cell mass in the batch culture in which the glucose was consumed and the respiratory activity of the actively growing cells (that obtained for the middle G1-to S-phase cells) enabled us to determine a balance sheet for the production of the algal cells from the nutrients in terms of the four major elements, as follows:

$$
\begin{gathered}
\begin{array}{r}
1.644 \mathrm{C}_{6} \mathrm{H}_{12} \mathrm{O}_{6}+1.538 \mathrm{HNO}_{3} \longrightarrow \\
\mathrm{C}_{9.86} \mathrm{H}_{18.50} \mathrm{O}_{5.63} \mathrm{~N}_{1.34}+1.384 \mathrm{H}_{2}+7.464(\mathrm{O})
\end{array} \\
\begin{array}{c}
\text { 7.464 }(\mathrm{O})+7.464 / 12 \mathrm{C}_{6} \mathrm{H}_{12} \mathrm{O}_{6} \longrightarrow 3.732 \mathrm{CO}_{2}+3.732 \mathrm{H}_{2} \\
\text { 4.57 } \mathrm{O}_{2}+4.57 / 6 \mathrm{C}_{6} \mathrm{H}_{12} \mathrm{O}_{6} \longrightarrow 4.57 \mathrm{CO}_{2}+4.57 \mathrm{H}_{2} \mathrm{O}
\end{array} \\
\begin{array}{c}
3.03 \mathrm{C}_{6} \mathrm{H}_{12} \mathrm{O}_{6}+1.54 \mathrm{HNO}_{3}+4.58 \mathrm{O}_{2} \longrightarrow \\
\mathrm{C}_{9.86} \mathrm{H}_{18.5} \mathrm{O}_{5.63} \mathrm{~N}_{1.54}+8.32 \mathrm{CO}_{2}+9.69 \mathrm{H}_{2}
\end{array}
\end{gathered}
$$

Thus, $545 \mathrm{mg}$ of glucose is utilized to produce the algal cells of $1 \mathrm{ml}$ PCV ( $=250 \mathrm{mg}$ dry weight) using nitrate as the nitrogen source; $22 \mathrm{gm}$ of glucose should yield $40.4 \mathrm{ml}$ cells. This value agrees well with the experimentally obtained value of $41.6 \mathrm{ml}$, indicating the validity of the equation. Hence, the efficiency in converting glucose into the algal cell mass using nitrate as the nitrogen source was $54 \%$. Forty-six percent of the total glucose given was utilized for the biosynthetic energy source by complete oxidation. Thus, the algal cells consumed $53 \mathrm{mmol}$ of ATP to produce $1 \mathrm{ml} \mathrm{PCV}$ cells or $250 \mathrm{mg}$ cell mass using glucose and nitrate (provided 38 moles of ATP were produced from one mole of glucose by the complete oxidation).

\section{REFERENCES}

1. Aoshima, J., T. Nishimura and T. Imamura. DNA polymerases of Chlorella. I. Chloroplastic and nuclear DNA polymerases in synchronized algal cells. Cell Struct. Funct. 7, 327-340, 1984

2. ESTABROOK, R.W. Mitochondrial respiratory control and the polarographic measurement of ADP:O ratios. Meth. Enzymol. 10, 41-47, 1967

3. HASE, E., Y. Morimura and H. TAmiYa. Some data on the growth physiology of Chlorella studied by the technique of synchronous culture. Arch. Biochem. Biophys. 69, 149-165, 1957

4. Iтон, J., T. Nishimura, and T. Iwamura (unpublished data).

5. IwAmura, T. Change of nucleic acid content in Chlorella cells during the course of their life-cycle. J. Biochem. (Tokyo) 67, 575-589, 1955

6. Iwamura, T. Nucleic acids in chloroplasts and metabolic DNA. Progr. Nucleic Acid Res. \& Molecular Biol. 5, 133-155, 1965

7. Iwamura, T. DNA species in algae. Annl. New York Acad. Sci. 171, 488-510, 1979

8. Iwamura, T., K. KatoH and T. Nishimura. Semi-conservative replication of chloroplast DNA in 
synchronized Chlorella. Cell Struct. Funct. 7, 71-86, 1982

9. IWAmURA, T., H. NAGAI, and S. ICHIMURA. Improved methods for determining contents of chlorophyll, protein, ribonucleic acid and deoxyribonucleic acid in planktonic populations. Int. Rev. Ges. Hydrobiol. 55, 131-147, 1970

10. Kanazawa, T. Synchronous culture of Chlorella with special reference to the process of assimilation of potassium, magnesium, and iron. J. Gen. Appl. Microbiol. 4, 102-107, 1958

11. NefF, R.J. and R.H. NEFF. Induction of synchronous division in amoebae. In Synchrony in Cell Division and Growth, ed. Zeuthen, E., Interscience Publ., N. Y., pp. 213-246, 1964

12. Ogur, M., S. Minckler, and D.O. MClaRY. Deoxyribonucleic acid and the budding cycle in the yeasts. J. Bacteriol. 66, 642-645, 1953

13. Takabayashi, A., T. Nishimura and T. Iwamura. Incorporation of radioactive tracers of some labelled compounds into DNA, RNA and protein in Chlorella cells at various stages of the cell cycle in synchronous culture. J. Gen. Appl. Microbiol. 22, 183-196, 1976

14. Tamiya, H., Synchronous culture of algae. Ann. Rev. Plant Physiol. 17, 1-26. 1966

15. Tamiya, H., T. Iwamura, K. Shibata, E. Hase, and T. Nihei. Correlation between photosynthesis and light-independent metabolism in the growth of Chlorella. Biochim. Biophys. Acta 12, 23-40, 1953

(Received for publication, March 8, 1988) 